\title{
Mortality trends due to chronic obstructive pulmonary disease in Brazil
}

\author{
Gustavo Silveira Graudenz ${ }^{1,2 *}$, Gabriel Pereira Gazotto ${ }^{1}$ \\ ${ }^{1}$ Medical Sciences Department, Nove de Julho University, São Paulo, SP. \\ ${ }^{2}$ Master Program in Environmental Management and Sustainability, Nove de Julho University, São Paulo, SP.
}

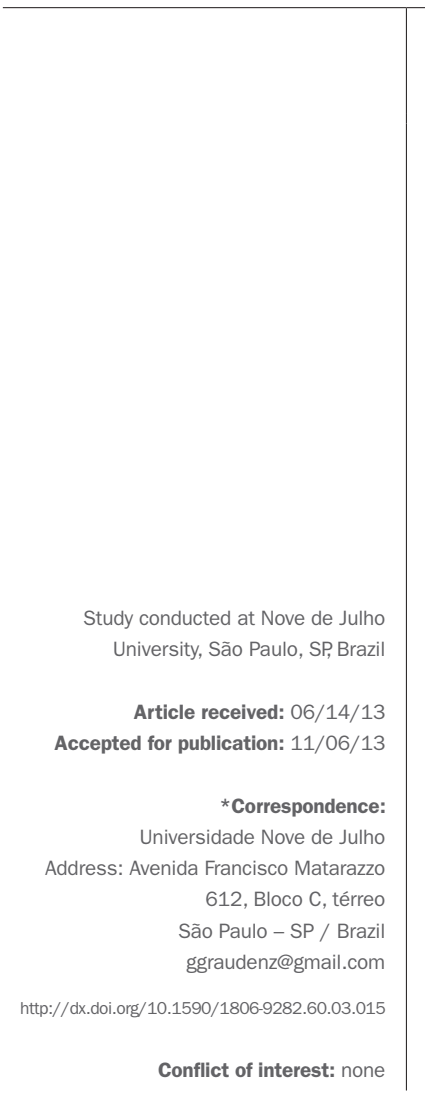

\section{SUMmARY}

Objective: the purpose of this study was to update and analyze data on mortality trend due to chronic obstructive pulmonary disease (COPD) in Brazil.

Methods: initially, the specific COPD mortality rates were calculated from 1989 to 2009 using data collected from DATASUS (Departamento de Informática do SUS - Brazilian Health System Database). Then, the polynomial regression models from the observed functional relation were estimated based on mortality coefficients and study years.

Results: we verified that the general mortality rates due to COPD in Brazil showed an increasing trend from 1989 to 2004, and then decreased. Both genders showed the same increasing tendencies until 2004 and decreased thereafter. The age group under 35 years old showed a linear decreasing trend. All other age groups showed quadratic tendencies, with increases until the years of 1998-1999 and then decreasing. The South and Southeast regions showed the highest COPD mortality rates with increasing trends until the years 2001-2002 and then decreased. The North, Northeast and Central-West regions showed lower mortality rates but increasing trend.

Conclusion: this is the first report of COPD mortality stabilization in Brazil since 1980 .

Key words: chronic obstructive pulmonary disease; mortality; international classification of diseases.

\section{INTRODUCTION}

According to the Global Initiative for Chronic Obstructive Lung Disease (GOLD), published in 2001, "chronic obstructive pulmonary disease (COPD) is a respiratory disease characterized by the presence of chronic airflow obstruction that is not fully reversible. ${ }^{1}$ The airflow obstruction is usually progressive and associated with an abnormal inflammatory response of the lungs to inhaled particles or toxic gases. Over the last few years, COPD has had a great emphasis in view of the awareness regarding its importance as a morbidity and mortality factor. The World Health Organization (WHO) estimates that COPD affects 210 million people worldwide, with approximately 64 million symptomatic cases. ${ }^{2}$

COPD symptoms are similar to asthma's - which is another chronic obstructive respiratory disease whose clinical features often overlap COPD's. However, in asthma, the air- flow obstruction is reversible, as opposed to COPD, with poor response to bronchodilators observed in spirometry.

COPD is a consolidated challenge to public health in Brazil. In 2010, over 127.000 patients were admitted to public hospitals diagnosed with this disease, according to the International Classification of Diseases (ICD-10); and over 37.000 deaths were due to COPD, according to Mortality Information System/Sistema Único de Saúde (SUS Brazilian Unified Health System). The Global Burden of Disease Study projected that in 2020, COPD will account for $4.1 \%$ of the total of disability-adjusted life years (DALYs) and will rank fifth in lost DALYs - after ischemic heart disease, major depression, traffic accidents and cerebrovascular disease. ${ }^{3}$

The Platino study described the prevalence of COPD in five Latin American countries, including Brazil. It was 
estimated that $14.3 \%$ of a 85 million population over 40 years old was affected. ${ }^{4} \mathrm{~A}$ regional follow-up of that study with the population from the city of São Paulo - using spirometry as a gold standard diagnostic test - demonstrated a COPD prevalence of $15.8 \%, 87.5 \%$ of which had never been previously diagnosed, revealing low awareness and underestimation of COPD as a major concern. ${ }^{5}$ In a previous prevalence study using SUS database, Campos demonstrated a significant increase in COPD mortality in Brazil from 1980 to $1998 .{ }^{6}$ In this study, the author reported a 3.3 fold overall increase in absolute mortality due to COPD, especially among patients aged 65 years and older, and high mortality rates in the country's South and Southeast regions. Hospital admission due to COPD had the highest mortality rates $(12.2 \%)$ of all respiratory causes in the city of Sao Paulo from 1995 to $2000 .^{7}$ Given COPD's increasing importance as a cause of death in most countries, an updated analysis on COPD mortality is needed to support control and prevention policies.

\section{Objective}

To update data and analyze mortality trends due to COPD in different Brazilian regions according to different age and gender groups, from 1989 to 2009.

\section{Methods}

In this study, data on COPD mortality from 1989 to 2009 was collected from the DATASUS (Departamento de Informática do SUS - Brazilian Health System Database) Mortality Information System of the Ministry of Health (SIM/DATASUS). For data selection, we used the International Classification of Diseases version 9 (ICD9) for deaths before 1996 (i.e., 1989-1995) and ICD10 for deaths thereafter. ICD9 included codes 490, 491, 492 and 496. For ICD10, J40, J41, J42, J43 and J44 codes were chosen. Using these codes, both the general standardized mortality rate (GSMR) and the specific mortality rate (SMR), disaggregated by gender, age or by the regional population estimation, were calculated annually using demographic stratified data according to Brazil's periodic census and historic population estimations provided by DATASUS. Rates were given per 100.000 individuals. While modeling polynomial coefficients, COPD mortality rates were considered as the dependent variable $(\mathrm{Y})$, and calendar years as, the independent variable $(X)$. As a measure of accuracy of the model, the determination coefficient $\left(R^{2}\right)$ was used.

The models were tested for linear $(\mathrm{Y}=\beta 0+\beta 1 \mathrm{X})$, qua$\operatorname{dratic}(\mathrm{Y}=\beta 0++\beta 1 \mathrm{X} \beta 2 \mathrm{X} 2)$, cubic $(\mathrm{Y}=\beta 0+\beta 1 \mathrm{X} \beta 2 \mathrm{X} 2+$ $+\beta 3 \mathrm{X} 3)$ and exponential $(\mathrm{Y}=\beta 0+$ and $\beta 1 \mathrm{X})$ fit. SPSS ver- sion 19 was used for statistical analysis. Trends were considered significant at the $p<0.05$ level. In those models, $\beta 0$ was the period average coefficient (intercept) and the $\beta 1$, the average annual increment (linear effect coefficient).

\section{Results}

Table 1 shows regression coefficients and statistical significance of COPD mortality rate trend according to gender, age, and region in Brazil. Figure 1 shows standard and gender COPD mortality rates in Brazil. GSMR increased from 1980 to 2004, with 19.84 deaths per 100.000 residents, but declined after that. COPD SMR according to gender shows an upward trend in both genders until 2004, reaching 24.52 male and 15.04 female deaths per 100.000 inhabitants; but again, declined after that.

The evolution of age-adjusted COPD mortality rates per 100.000 individuals of the same age group is illustrated in Table 1. A significant difference in SMR was observed according to age groups. The segment which comprises 0 to 34 year olds showed SMR below 2 per 100.000 deaths of age-adjusted individuals; however, it shows a linear downward trend with decrease of 0.009 deaths per year in COPD SMR. The segment comprising 35 to 44 year olds showed mortality rate values ranging from 1.25 , in 2009 , to 1.97 , in 1996 - better adjusted to the quadratic model -, with increasing trend until 1998, and then decreasing. The age group from 45 to 54 years showed SMR ranging from 7.63, in 2007 , to 10.17 , in 1999, with rising trend until 1998, and after that, demonstrated a non-constant decrease of 0.04 SMR per year. The age group from 55 to 64 years shows SMR ranging from 31.28 , in 2009 , to 48.28 , in 1998 . The trend increased until 1998; after that, decreased at a nonconstant rate of 0.328 cases per year, already with negative acceleration. COPD SMR values for people aged 65 years and older show a variation from 281.35 , in 1998 , to 187.49 , in 1989, with an average of 268.20 SMR during the analyzed period. The age-adjusted model shows an increasing trend until 1992; after that, a decrease.

There is great heterogeneity in COPD SMR in all Brazilian regions, as shown in Figure 2. The South region shows the largest COPD SMR throughout the sampling period, with a mean coefficient of 36.46 per 100.000 inhabitants and an increasing trend until 2002, followed by a decrease with a negative acceleration of 0.09 deaths per year after that. The Southeast region is the second most important regarding COPD SMR, with average coefficients of 21.99 during the analyzed period. It shows an upward trend until 2001; after that, it decreases. Both regions show an increasing trend of SMR until 2001 and 2002 , followed by a stabilization period until 2004, and 
a downward turning point. The Central-West region shows intermediate position of SMR with a non-constant upward trend and an increase of 0.56 cases per year, with a final trend towards stabilization at a high level. The Northeast and North regions overleap with low levels of COPD SMR; however, with an increasing trend of SMR, although the North region has indications of slowing down the rising trend due to negative acceleration.

\section{Discussion}

This study shows a stabilization trend, or even a decline, in COPD mortality in Brazil, compared to a previous study using the same methodology. ${ }^{6}$ Similar results have been published recently. A decrease of COPD mortality in both genders, from 1996 to 2007, had already been reported in Canada. ${ }^{8}$ Additionally, data from England and Wales showed a reduction in COPD mortality in men, but an increase among women. ${ }^{9}$ The decreasing trend mortality due to obstructive lung diseases in Brazil had already been reported in a previous study; however, it couldn't be compared to the present study, as it included ICD data related to asthma (J45-0). ${ }^{10}$ This is the first study using this methodology to report a decrease in COPD trends in Brazil, according to the authors' knowledge.

Epidemiological studies using death certificates are biased information. Under or misreporting COPD deaths cannot be excluded, especially in regions where coverage of vital statistics depends on the hospital structure. Moreover, there are other information bias due to diagnostic limitations and inaccuracies at the time of the death certificate. ${ }^{11-13}$ Another possible source of information bias refers to different disease interpretations provided by ICD, which consequently leads to different results in COPD epidemiology. Additionally, ICD change from version 9 to 10, in 1996, may have led to different results. To decrease information biases, this review was made using the same study parameters of COPD mortality in Brazil, from 1989 to $1998 .{ }^{6}$

This study shows a current stabilization or decrease trend in COPD mortality in Brazil, based on SUS database. After the steady increase starting in 1989, there was an inflection point in the curve in 1998. When looking at the mortality curve according to gender, there is a declining trend after 2004 in both genders. In 1998, the COPD mortality rate ratio between male/female decreased from 1.64 , to 1.51 in 2009 . This finding contrasts with the increased trends in COPD mortality among women, compared to men, as reported in North American epidemiological studies (Table 1 and Figure 1). ${ }^{14,15}$

Not only gender, but also all age groups, showed a stabilization or decrease trend in COPD deaths after 1999
(Table 1 and Figure 2). The age group comprising 65 yearolds or older had higher COPD SMR rates. This age group is historically very representative in overall COPD deaths. ${ }^{6}$ It fits well in a quadratic model $\left(R^{2}=0.739\right)$ with a declining turning point after 1999, and it significantly contributed to the trend's overall decline. With the increase in life expectancy, further studies are needed in this age group to monitor control measures of this important disease in Brazil's aging population.

The causes of this decrease in COPD mortality are still unknown. They can be associated to new health policies aiming at providing better access for patients to health services, as demonstrated in some other avoidable mortality diseases. ${ }^{16}$ The introduction of new therapies, such as oxygen therapy and new drugs, has also shown an increase in survival among COPD patients in moderatesevere stages, ${ }^{1,17}$ and it could be contributing to the change in COPD mortality trend.

COPD epidemiology shows a close relationship with smoking and other domiciliary and occupational exposures. Smoking is the main risk factor, accounting for approximately $90 \%$ of COPD patients; and, consequently, the most studied risk factor $(1,2)$. As a result, a potential contributing factor to the decline in COPD mortality may be related to the changes in smoking habits in Brazil during the analyzed period. According to a non-continued analysis across three different studies on smoking prevalence among the population - the Brazilian Health and Nutrition Survey (PNSN - Pesquisa Nacional de Sańde e Nutrição) ${ }_{18}^{18}$ the World Health Survey (Pesquisa Mundial de Saúde) ${ }^{19}$ and the Brazilian Household Survey (PNAD - Pesquisa Nacional por Amostras de Domicilios) ${ }^{20}$-, the prevalence of adult smokers aged 18 years and older have dropped from $34.8 \%$, in 1989 , to $21 \%$, in 2003 , reaching $17.2 \%$, in 2008.

Further research on the smoking prevalence in Brazil showed a reduction in smoking habits among all age groups, the sharpest decline being among the youngest (<35 years old) and the oldest ( $>65$ years old). ${ }^{21}$ PNAD 2008 - with emphasis on smoking - shows data of great interest for understanding the Brazilian smoker profile. It demonstrates an inverse relationship between smoking and per capita income, especially in the South and Southeast regions. This study also suggests that the educational level influences the age people start smoking - among people with no education or less than a year of study, the proportion of those who started smoking before the age of 15 reaches $40.8 \% .^{22}$

In a recent meta-analysis on the subject, Godtfredsen et al. report an increased survival time and a decreased 
TABLE 1 COPD Mortality Rates

\begin{tabular}{|c|c|c|c|c|c|c|}
\hline $\begin{array}{l}\text { COPD mortality rate } \\
\text { per } 100.000 \\
\text { inhabitants }\end{array}$ & $\begin{array}{l}\text { Period } \\
\text { average } \\
\text { coefficient }\left(\beta_{0}\right)\end{array}$ & $\begin{array}{l}\text { Average } \\
\text { annual } \\
\text { increment }\left(\beta_{1}\right)\end{array}$ & $\begin{array}{l}\text { Acceleration } \\
\left(\beta_{2}\right)\end{array}$ & $\begin{array}{l}P \\
\text { value } \\
(F)\end{array}$ & $\begin{array}{l}\text { Adjusted } \\
\text { R2 }\end{array}$ & Trend \\
\hline \multicolumn{7}{|l|}{ 1- General } \\
\hline Brazil & 18.226 & 0.324 & $-0,033$ & $<0.001$ & 0.916 & $\begin{array}{l}\text { Increasing until } 2004 \text { and then } \\
\text { decreasing }\end{array}$ \\
\hline \multicolumn{7}{|l|}{ 2-Gender } \\
\hline Male & 22.886 & 0.34 & $-0,043$ & $<0.001$ & 0.911 & $\begin{array}{l}\text { Increasing until } 2004 \text { and then } \\
\text { decreasing }\end{array}$ \\
\hline Female & 13.650 & 0.31 & -0.023 & $<0.001$ & 0.923 & $\begin{array}{l}\text { Increasing until } 2004 \text { and after } \\
\text { decreasing }\end{array}$ \\
\hline \multicolumn{7}{|l|}{ 3- Age Group } \\
\hline $0-34$ old $^{1}$ & $1.270^{*}$ & 0.962 & & $<0.001$ & 0.8 & $\begin{array}{l}\text { Decreasing, stabilizing } \\
\text { at low level }\end{array}$ \\
\hline $35-44$ old $^{2}$ & 1.829 & -0.023 & -0.004 & $<0.001$ & 0.749 & $\begin{array}{l}\text { Increasing until } 1998 \text { and then } \\
\text { decreasing }\end{array}$ \\
\hline $45-54$ old $^{3}$ & 9.261 & -0.043 & -0.012 & 0.001 & 0.47 & $\begin{array}{l}\text { Increasing until } 1998 \text { and then } \\
\text { decreasing }\end{array}$ \\
\hline $55-64$ old $^{4}$ & 44.527 & -0.328 & -0.114 & $<0.001$ & 0.757 & $\begin{array}{l}\text { Increasing until } 1998 \text { and then } \\
\text { decreasing }\end{array}$ \\
\hline$>65$ yearsold ${ }^{5}$ & 268.201 & 1.604 & -0.670 & $<0.001$ & 0.739 & $\begin{array}{l}\text { Increasing until } 1999 \text { and then } \\
\text { decreasing }\end{array}$ \\
\hline \multicolumn{7}{|l|}{ 4- Region } \\
\hline South & 36.459 & 0.482 & -0.09 & $<0.001$ & 0.758 & $\begin{array}{l}\text { Increasing until } 2002 \text { and then } \\
\text { decreasing }\end{array}$ \\
\hline Southeast & 21.995 & 0.2 & -0.043 & $<0.001$ & 0.819 & $\begin{array}{l}\text { Increasing until } 2001 \text { and then } \\
\text { decreasing }\end{array}$ \\
\hline Central-West & 17.109 & 0.561 & -0.026 & $<0.001$ & 0.921 & Increasing, stabilizing at a high level \\
\hline Northeast & $374.278^{*}$ & 1.069 & & $<0.001$ & 0.987 & Increasing \\
\hline North & 7.060 & 0.363 & -0.007 & $<0.001$ & 0.956 & Increasing, stabilizing at a high level \\
\hline
\end{tabular}

* Exponential values.

Note: Best Fitting model for age groups.

${ }^{2}$ Cubic model.

${ }^{3}$ Quadratic model.

${ }^{4}$ Quadratic model.

${ }^{5}$ Quadratic model.

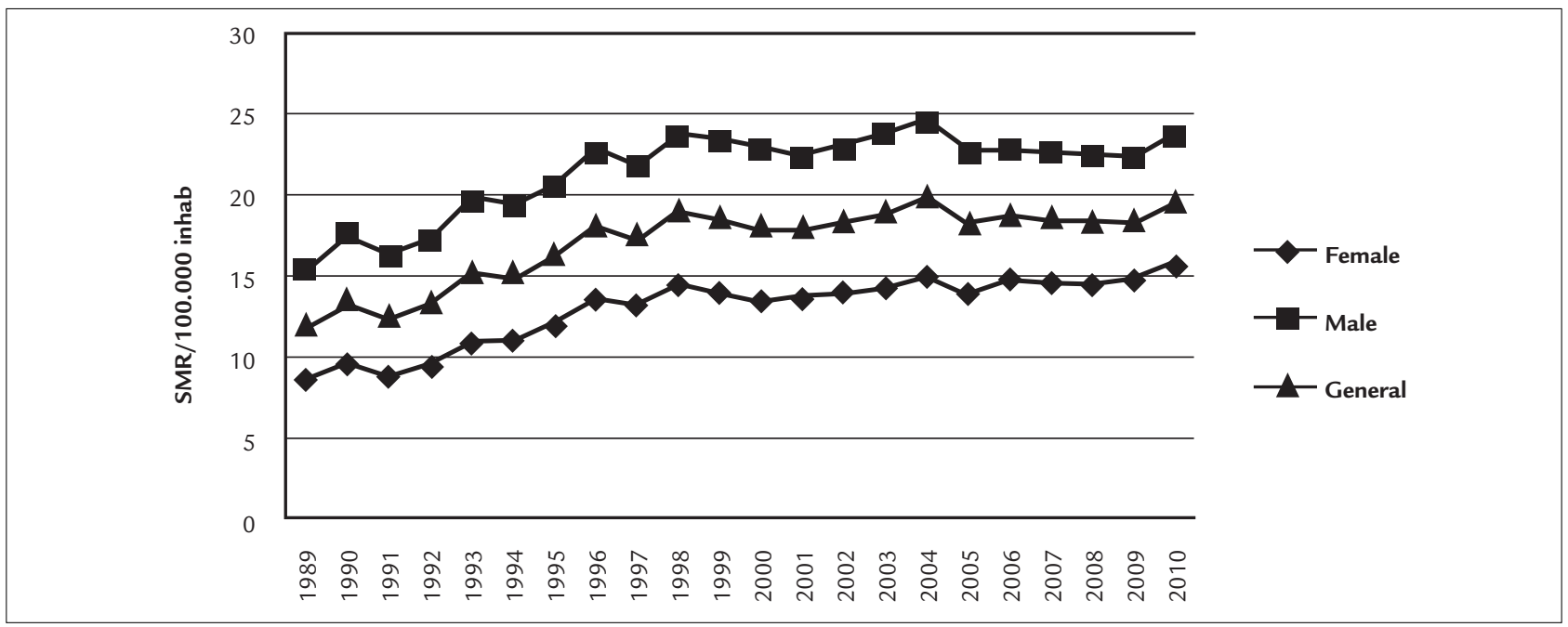

FIGURE 1 COPD mortality rates specific (by gender) and general annual COPD mortality rate (per 100.000 inhabitants). 


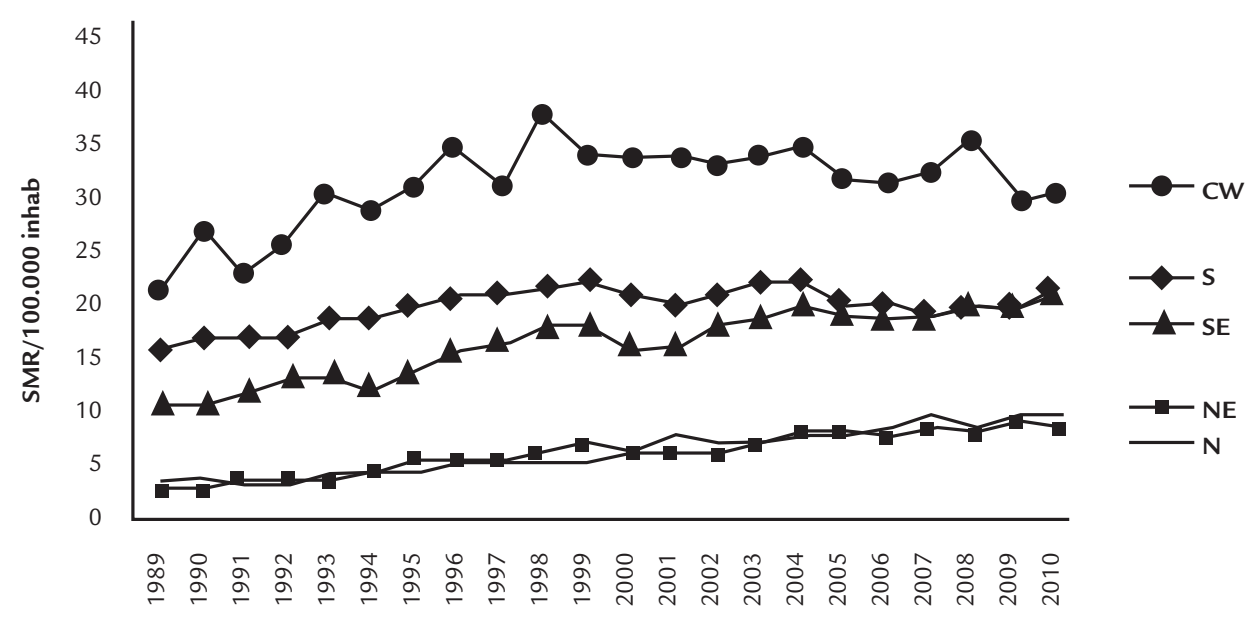

FIGURE 2 CPOD mortality by regions specific annual COPD mortality rate by regions of Brazil (per 100.000 inhabitants).

rate of lung function loss, even in severe COPD, compared with those who did not stop smoking. ${ }^{23}$ However, the expected time between the decrease in smoking prevalence observed in a population and its subsequent decline in mortality rates due to tobacco-associated mortalities among that population remains largely speculative.

The global initiative against COPD recommends influenza vaccination in patients with COPD with level of evidence A. ${ }^{1}$ In that sense, in 1999, a mass vaccination against influenza (seasonal influenza) was established in Brazil for individuals older than 65 years as a strategy of the Ministry of Health. This strategy would potentially benefit COPD patients within this age group who had a higher mortality rate, even those without medical diagnosis of COPD. In a time series study, Francis et al. investigated the impact on mortality among the elderly due to this vaccination. The authors demonstrated a reduction in mortality from 2000 to 2001; however, it increased again after 2002 , especially in the age group above 75 years old. ${ }^{24}$ Two other studies, one conducted in the state of Ceará and the other in the state of São Paulo, showed similar results with a significant decrease in the number of deaths and in mortality rate due to respiratory and cardiac causes from 2000 to 2001 , with increased mortality in later years. ${ }^{25,26}$

A noteworthy study on mortality among the elderly in Brazil from 1980 to 2005, shows an increase in mortality related to influenza among the elderly, more pronounced in the South and Southeast regions, and among men older than 80 years, despite vaccination. ${ }^{27}$ The reasons for these mixed results after vaccination campaigns are deficiencies in the coverage of the elderly population at risk ${ }^{28}$ and immunosuppressive factors related to the aging immune system, reducing vaccine protection. ${ }^{29}$

\section{Conclusion}

This study shows a general trend towards stabilization in the number of COPD deaths in Brazil, from 1989 to 2009, concurrent with a reduction in smoking prevalence and the introduction of mass vaccination against influenza for the elderly in the same period. Despite the reduction of about 50\% in the number of smokers in Brazil during the same period, it is not yet possible to correlate this fact with the development of COPD mortality due to lack of data continuity on smoking. However, continued efforts must be maintained as a public health priority in smoking prevention, especially among the most vulnerable classes, as well as to implement measures to extend coverage rates of vaccination campaigns against influenza to reduce COPD mortality.

\section{Acknowledgements}

We would like to thank Fundação de Amparo à Pesquisa do Estado de São Paulo (FAPESP - Foundation for Research Support of the State of São Paulo, grant number 2012/028484) for funding this study.

\section{Resumo}

Tendências de mortalidade por doença pulmonar obstrutiva crônica no Brasil 
Objetivo: o objetivo deste artigo foi de atualizar e analisar a tendência da mortalidade por doença pulmonar obstrutiva crônica (DPOC) no Brasil.

Métodos: inicialmente, foram calculadas as taxas de mortalidade específica por DPOC entre 1989 e 2009 por meio do Departamento de Informática do SUS (Datasus). Depois, foram estimados os modelos de regressão polinomial a partir da relação funcional entre as taxas de mortalidade e os anos de estudo.

Resultados: verificou-se que as taxas de mortalidade geral por DPOC no Brasil mostraram uma tendência de aumento de 1998 até 2004 e, depois, uma diminuição. Essa mesma tendência de aumento até 2004 e, em seguida, diminuição semelhante para ambos os sexos. A faixa etária abaixo de 35 anos mostrou tendência de queda linear, enquanto as outras faixas etárias mostraram tendências quadráticas com aumento entre os anos de 1998 e 1999 e, após, queda. As regiões Sul e Sudeste mostraram as taxas de mortalidade mais altas com tendências crescentes até os anos de 2001 e 2002 e, após, decrescentes. As regiões Norte, Nordeste e Centro-Oeste mostraram taxas de mortalidade mais baixas, mas com tendência de elevação.

Conclusão: este é o primeiro relato de estabilização da mortalidade por DPOC no Brasil desde 1980.

Unitermos: doença pulmonar obstrutiva crônica; mortalidade/tendências; classificação internacional de doenças.

\section{RefEREnCES}

1. Rabe KF, Hurd S, Anzueto A, Barnes PJ, Buist SA, Calverley P et al. Global strategy for the diagnosis, management, and prevention of chronic obstructive pulmonary disease: GOLD executive summary. Am J Resp Crit Care Med. 2007; 176(6):532-55

2. OMS. Organização Mundial de Saúde. The burden of chronic obstructive disease. 2004. Fact sheet N. 315 November 2012. Available from: http:// www.who.int/mediacentre/factsheets/fs315/en/.

3. Murray CJL, Lopez AD. The global burden of disease: a comprehensive assessment of mortality and disability from diseases, injuries and risk factors in 1990 and projected to 2020. Cambridge, Harvard University Press; 1996. v.1: The Global Burden of Disease and Injury Series.

4. Menezes AM, Perez-Padilla R, Hallal PC, Jardim JR, Muino A, Lopez MV et al. Worldwide burden of COPD in high- and low-income countries. Part II. Burden of chronic obstructive lung disease in Latin America: the PLATINO study. Int J Tuberc Lung Dis. 2008;12(7):709-12.

5. Nascimento OA, Camelier A, Rosa FW, Menezes AM, Perez-Padilla R, Jardim JR. Chronic obstructive pulmonary disease is underdiagnosed and undertreated in Sao Paulo (Brazil): results of the PLATINO study. Braz J Med Biol Res. 2007;40(7):887-95.

6. Campos HS. Mortalidade por DPOC no Brasil, 1980-1998. Pulmão RJ. 2003;12(4):217-25.

7. Toyoshima MTK, Ito GM, Gouveia N. Morbidade por doenças respiratórias em pacientes hospitalizados em São Paulo/SP. Rev Assoc Med Bras. 2005;51(4):209-13.
8. Gershon AS, Wang C, Wilton AS, Raut R, To T. Trends in chronic obstructive pulmonary disease prevalence, incidence, and mortality in ontario, Canada, 1996 to 2007: a population-based study. Arch Intern Med. 2010;170(6):560-5.

9. Lopez AD, Shibuya K, Rao C, Mathers CD, Hansell AL, Held LS et al. Chronic obstructive pulmonary disease: current burden and future projections. Eur Resp J. 2006;27(2):397-412.

10. Bensenor IM, Fernandes TG, Lotufo PA. Chronic obstructive pulmonary disease in Brazil: mortality and hospitalization trends and rates, 1996-2008. Int J Tuberc Lung Dis. 2011;15(3):399-404.

11. Schramm J, Szwarcwald CL. Sistema hospitalar como fonte de informação para estimar a mortalidade neonatal e a natimortalidade. Rev Saúde Pública. 2000;34(3):272-9.

12. Duncan BB, Rumel D, Zelmanowicz A, Mengue SS, Santos SD, Dalmaz A. Social inequality in mortality in São Paulo State, Brazil. Int J Epidemiol. 1995;24(2):359

13. Oliveira A, Valente J, Leite I. Aspectos da mortalidade atribuível ao tabaco: revisão sistemática. Rev Saúde Pública. 2008;42(2):335-45.

14. Mannino DM, Homa DM, Akinbami LJ, Ford ES, Redd SC. Chronic obstructive pulmonary disease surveillance-United States, 1971-2000. MMWR Surveill Summ. 2002;51(6):1-16.

15. Brown DW, Pleasants RA. Mortality from chronic obstructive pulmonary disease among adults aged 25 years or older in North Carolina. South Med J. 2011;104(1):20-3.

16. Malta DC, Duarte EC. Causas de mortes evitáveis por ações efetivas dos serviços de saúde: uma revisão da literatura. Ciênc Saúde Coletiva. 2007;12(3):765-76.

17. Machado MC, Vollmer WM, Togeiro SM, Bilderback AL, Oliveira MV, Leitão FS et al. CPAP and survival in moderate-to-severe obstructive sleep apnoea syndrome and hypoxaemic COPD. Eur Resp J. 2010;35(1):132-7.

18. IBGE. Panorama do tabagismo no Brasil. Pesquisa Nacional em Saúde e Nutrição; 1989.

19. Szwarcwald CL, Viacava F. Pesquisa Mundial de Saúde: o Brasil em números. RADIS: Comunicação em Saúde. 2004;23:14-33. Disponível em: http://arca. icict.fiocruz.br/handle/icict/655.

20. IBGE. Pesquisa Nacional por Amóstras de Domicílios. 2009. Disponível em: http://www.ibge.gov.br/home/estatistica/populacao/trabalhoerendimento/ pnad2009/.

21. Monteiro CA, Cavalcante TM, Moura EC, Claro RM, Szwarcwald CL. Population-based evidence of a strong decline in the prevalence of smokers in Brazil (1989-2003). Bull World Health Org. 2007;85(7):527-34.

22. IBGE. Pesquisa Especial sobre o Tabagismo. Pesquisa nacional de amostras por domicílios. 2008. Available from: http://www.ibge.gov.br/home/ estatistica/populacao/trabalhoerendimento/pnad2008/suplementos/ tabagismo/default.shtm.

23. Godtfredsen N, Lam T, Hansel T, Leon M, Gray N, Dresler C et al. COPDrelated morbidity and mortality after smoking cessation: status of the evidence. Eur Respir J. 2008;32(4):844.

24. Francisco PMSB, Donalisio MRC, Lattorre MRDO. Impact of influenza vaccination on mortality by respiratory diseases among Brazilian elderly persons. Rev Saúde Pública. 2005;39(1):75-81.

25. Façanha MC. Impacto da vacinação de maiores de 60 anos para influenza sobre as internaçõeses e hábitos por doenças respiratórias e circulatórias em Fortaleza-CE-Brasil. J Bras Pneumol. 2005;31(5):415-20.

26. Donalisio MR, Francisco PMSB, Latorre MRDO. Tendência da mortalidade por doenças respiratórias em idosos antes e depois das campanhas de vacinação contra influenza no Estado de São Paulo-1980 a 2004. Rev Bras Epidemiol. 2006;9(1):32-41.

27. Souza A, Dourado I, Duarte EC, Daufenbach LZ. Mortalidade por causas relacionadas à influenza em idosos no Brasil, 1992 a 2005. Epidemiologia e Serviços de Saúde. 2009;18(3):209-18.

28. Donalisio MR, Ruiz T, Cordeiro R. Fatores associados à vacinação contra influenza em idosos em município do Sudeste do Brasil. Rev Saúde Pública. 2006;40(1):115-9

29. Targonski PV, Jacobson RM, Poland GA. Immunosenescence: role and measurement in influenza vaccine response among the elderly. Vaccine. 2007;25(16):3066-9. 


\section{Abbreviations}

1. COPD: Chronic Obstructive Pulmonary Disease

2. ICD: International Classification of Diseases

3. SUS: Sistema Único de Saúde [Unified Brazilian Health System]

4. SMR: Specific mortality rate

5. GSMR: General standardized mortality rate

6. GOLD: Global Initiative for Chronic Obstructive Lung Disease
7. DATASUS: Departamento de Informática do SUS [SUS Department of Informatics - Brazilian Health System Database]

8. SIM/DATASUS: Sistema de Informação de Mortalidade do DATASUS [DATASUS Mortality Information System]

9. WHO: World Health Organization

10. PNSN: Pesquisa Nacional de Saúde e Nutrição [Brazilian Health and Nutrition Survey]

11. WHS: World Health Survey

12. PNAD: Pesquisa Nacional por Amostras de Domicilios [Brazilian Household Survey ] 